\title{
Globalization and Public Sector Reform in Third World Countries: The Nigerian Experience
}

\author{
Ashaver, Benjamin Teryima
}

\begin{abstract}
The 1980 witnessed public sector reforms in third world countries in cognizance with global trends, done principally to re-align the economies of these countries on the path of recovery. Prior to the reforms, the economies of some of the countries were at the verge of collapse. In Africa especially countries that embraced public sector reforms did so wholesomely in line with International Monetary Fund and World Bank conditionalities. Generally the reforms did not produce the expected results. This has been largely attributed to faulty premise on which the reform programmes were anchored, lack of political will by leaders of these countries, lack of transparency in the implementation of the reform programmes, failure to clearly identify and articulate domestic imperatives vis-à-vis response to global necessities. For public sector reform to achieve desired results required getting the basic right.
\end{abstract}

As a worldwide phenomenon, administrative inform has been a widespread challenge to almost all national and sub-national governments around the globe. Unlike the reform movements of the earlier decades of the twentieth century, which emphasized institution building, bureaucratization, nationalization and a wide variety of organizational and administrative capacity building for national and economic development, the recent global phenomenon of administrative reform has been in the opposite direction: reversing the traditional role of government, the state, and public administrations into one that promotes a private, corporate-driven marketplace dominated by business elites.

Privatization, commercialization, marketization, and contracting out, together with a number of institutional changes, promote this new ideological trend on a global scale. Under the direct influence of globally dominated superpowers such as the United States and other Western donors, the World Bank, the International Monetary Fund, and the World Trade Organization, have forced almost all less- developed nations to structurally adjust their governments and administrative systems to these new global trends that promote globalization and enhance the power and profit of globalizing corporate elites (Farazmand 2002).

In this context of globalizing pressure, government of both industrialized and less-developed nations have engaged in extensive administrative reforms and reorganizations to streamline their public sectors by shrinking their size, function and activities. The need to inform traditional governmental organization and administration is to improve administrative machineries, to reduce or eliminate duplication and waste and to increase productivity in public sector management.

However, it has been obvious that the "big push" originating from the United States and Britain in the 1980s to privatize, marketize, and commercialize and contract out the public sector functions has been driven by ideological as well as economic underpinnings of the market place as a supreme institution in running the economy and society.

That the new global administrative reforms must be modernized on the market driven ideological premises have been discovered by many developing counties to be faculty and are tilting towards adopting a balance approach to administrative reform in governance. The central issues of equality, fairness, and market failure are resurfacing as government after government realizes that the lives of the majority, the ordinary citizens, cannot be ignored in favour of the few - the powerful particularistic interest group elite. Therefore, despite the growth of the "new public management" modeled after the private sector corporate management ideology, a more balanced trend of administrative reform is gradually emerging that reflects prudence and pragmatic approaches to government administration that must serve the broad-based public interests in nations.

This paper aims at examining the much desired change the internationally induced public sector reforms have brought on the economic processes in developing countries, with a particular reference to Nigeria. On the basis of findings, a way forward would be proffered. The write-up would be capped with a conclusion. 


\section{Definition Of Terms}

\section{Globalization}

The term "globalization" has acquired considerable emotive force. Some view it as a process which is beneficial - a key to future world economic development and also inevitable and irreversible. Others regards it with hostility, even fear, believing that it increases inequality between nations, threatens employment and living standards and thwarts social progress (Chittoo, et al 2009: 32). Globalization offers extensive opportunities for truly worldwide development but it is not progressing evenly. Some countries are becoming integrated into the global economy more quickly than others. Countries that have been able to integrate are seeing faster growth and reduced poverty as is the case in South East Asian countries.

Whether seen as a historical process or an ideological construct, globalization brings about greater interaction between countries, and between people. John Tomlinson (1996) defines it as "a rapidly developing process of complex interconnections between societies, cultures, institutions and individual's world-wide. It is a social process which involves a compression of time and space, shrinking distances through a dramatic reduction in the time taken - either physically or representationally - to cross them, so making the world seen smaller and in a certain sense bringing human beings closer to one another". Thomas Friedman (1996) sees it as "the loose combination of free - trade agreement, the internet and the integration of financial markets that is erasing borders and uniting the world into a single lucrative, but brutally competitive market place".

Globalization reduces the world into an integrated system of markets. In the process, international trade is considered to be the major engine of economic growth, and should therefore be facilitated. This facilitation is to be achieved through trade liberalization, necessitating the removal of tariff and non - tariff trade barriers. In addition, states are to withdraw from social provisioning by privatizing state social service organizations. The focus of the public sector will be one of policy formulation rather than implementation - a series of reforms collectively known as New Public Management (Chitto et al 2009:34).

As a matter of fact, during the past three decades there has been an unprecedented wave of reforms as the traditional model of public administration has come under attack. These reforms originated in developed industrial economics, whose political leaders were under pressure to keep down levels of public taxation and expenditure, while maintaining high level of welfare and other public services (Manning, 1996). A significant feature of the reforms was the belief that the state has become too large and over committed, and that the market offered superior mechanisms for achieving the efficient supply of goods and services (World Bank, 1996, 1997). As the reform movement has spread through globalization processes, reformers were faced with a choice between "old" public administration and "new" public management (DunLeavy, and Hood, 1994:9 - 16), with the additional dimension that the state is also expected to be responsible for the effective management of social and economic development, or "development management" (World Bank, 1997).

Scholars such as manning (2001: 297 - 312); and Minogue (2011) have attached the new public management, NPM, models for been flawed, advising that caution must be exercised in exporting it to developing countries. Chittoo and Gaojie, 2003; Spann 1981:12 25; Osborne \& Gacbler 1992; one Protagonist, while Schick, 1998; Allen 1999; and Sutch 1999: 1 -3, feel the model is flawed. Minogue, et al 1998; and Batley, 1999 have taken the middle course with the claim that its application has only brought mixed results far below its theoretical promises. We are in fact living in a world where most situations are grey. That they claim that the NPM model is somewhat outdated is exaggerated. The "public administration" and the "new public management" will co - exist with increasing pressure to adopt the new in the era of globalization (Chitto, et al, 2009: 35).

That governments and bureaucracies represent fixed costs in running countries and the public and the private sector as its customers have the right to ask for quality services at the lowest possible cost. These are the theoretical underpinnings of the NPM model. The fact that the results of its application in practice are mixed does not change the objectives of NPM nor its strategies. According to the protagonists, the problem lies, in implementation. Historical, sociological, cultural, or legal obstacles, plus lack of motivation and the limited capacity of governments will remain, the extent varying from one country to another. The World Bank (1995) acknowledges the problematic nature of implementation due to political obstacles to privatization; Nunberg (1995) notes the difficulty of applying developing country governance reform strategies that are rooted in the different cultures and superior resources of developed countries. While there is truth in these claims, the attitude is defeatist. Ibid.

\section{International Relations}

International relations, IR, or International Studies, IS, represents the study of foreign affairs and global issues among states within the international system, including the roles of states, inter - governmental non government organizations, INGO, and Multinational corporations, MNCs. It is both an academic and policy field and can be either positive or normative as it both seeks to analyses as well as formulate the foreign policy of particular states (Wikipedia, the free encyclopedia http://en.wikpedia.org/wiki/international_relations. the history 
of international relations is often traced backed to the peace of West Phalia of 1648, where the modern state system was developed. Prior to this, the European medieval organization of political authority was based on a vaguely, hierarchical religious order. West Phalia instituted the legal concept of sovereignty, which essentially meat that rulers, or the legitimate sovereigns, had no internal equals within a defined territory and no external superiors as the ultimate authority within the territory is sovereign borders. A simple way to view this is that sovereignty says "I am not allowed to tell you what to do and you are not allowed to tell me what to do". The contemporary international system was established through decolonization during the cold war. "Levels of analysis" is a way of looking at the international system, which includes the individual's level, the domestic nation - state as a unit, the international level of transactional and intergovernmental affairs, and the global level. Ibid.

\section{Third World Countries}

Third World refers to countries within the southern hemisphere i.e. that global south including countries of Africa, Asia and Latin America. They share basic commonalities in terms of characteristics and are more often referred to as countries of the Global South, developing countries, less developed economies, underdeveloped countries etc. The countries are characterized by under-development, subjugated and dependent economic systems as well as low standard of living for the majority of the people (Orngu, 2004:46 - 47) as compared to the industrially advanced nations of the world i.e. Western Europe, the United States, Canada, Austalia, New Zealand, the Communists World ( $2^{\text {nd }}$ World) and the Socialist countries of Eastern Europe.

\section{Theoretical Analysis Of Reform}

Theoretically, several perspectives may be defined to explain administrative reform. These perspectives reflect a body of knowledge in organization theory with various schools of thought for collective action. They range from classical, formal theories of organization, reorganization, and change and development to contemporary market theory, as well as the newest organizational elite theory that calls for fundamental change and reform in the structure and process of administrative systems (Farazmind 2002:3).

Guy Peters (1994) classifies most of this theoretical literature into three broad perspectives on administrative reform and reorganization - purposive (top - down) models, environmental (bottom - up) models and institutional models. These models are useful in explaining and understanding the approaches and motives of reforms and reorganization undertaken by modern governments. They also provide conceptual frameworks for analysis of organization and reorganization to modern governance and public administration. Finally, they help explain the relationship between reform and revolution in contemporary political and administrative systems.

While any of these models may apply in particular situations, governments may also use a combination of the three. It is important to make some distinction between reorganization - structural changes - and reform changes in procedures, processes, and relations within and among government administration (Guy Peters 1994).

This useful distinction may appear superficial, however, for the motivation and objectives of reforms and reorganizations they are often identical (Farazmand 2002: 3). Therefore, we will deal with them in this work as being synonymous.

\section{Top - Down Model}

The first set of theoretical models is a top - down model of government reform - is broadly purposive and top - down in its perspective on the process. This set of models assures that certain actors - elites, powerful individuals or authorities - have particular purpose in mind in the pursuit of reform and reorganization. These models assume that political leaders perceive problems or develop innovative ideas by reforming the public sector. One of these models is the "administration as usual" which is commonly used in the real world of public administration, where perceived needs for reform and reorganization are determined at the top.

The second strand of the top - down model is the "political science" approach which states that administrative reforms are determined by exigencies in the political environment. Guy Peter (1994:112) avers that although these modes are helpful they assure that the leading actors in the process are "central to identification, selection and implementation of administrative changes".

\section{Bottom - Up Environmentally Conditioning Models}

These models are considered bottom up approaches to administrative systems - structures - have to adapt to the environmental conditions that tend to dictate changes in the structure. The environment may be economic, political, cultural or social but the underlying logic of these approaches is very similar. There are many trends that explains this model, but its applicability to the international level is simply that of adaptability for instance since the 1980s, public services reform programmes were carried out in response to the external stimuli, especially from the demands emanating from the Bretton woods systems. With regards to national policy, the bottom - up approach provides opportunities for the inputs of those that the policy is intended to 
serve, for instance, the formulation of agricultural and poverty alleviation policies, where the target groups are allowed to contribute both to the formulation and implementation of such policies.

\section{Institutional Model}

The institutional models represent a separate group of approaches to reform and reorganization. In addition, they are both a reaction the earlier behavioural theories of organization and reorganization and a response to the inadequacy of the other models. Rather than viewing reforms as emanating from individual organizational/political leaders under purposive models focus on the need to modify collective values, culture, and structure to make the reform adaptive and dynamic (March and Olsen, 1984; Farazmand, 1994). Reform and reorganizations are more political and carry more significant values than is often perceived (Guy Peters, 1994).

This brief explanation is helpful in understanding and explaining government reforms, including for example, the Nigerian public sector reforms and reorganization, especially those that were carried out in response to the global environment induced by the international bodies like the World Bank. These models are also useful in drawing theoretical conclusions as to why some public reforms fail while others are useful, and yet the appearance of some successful reforms may have unintended negative consequences for the regime in power. This relevance does not necessarily mean that all reforms are doomed to fail various factors are involved in the outcomes of reforms. It is significant to note that all public sector reforms in Nigeria since the 1980s involved a top - down purposive approach utilizing a one - dimensional aspect of the institutional model - reforms based on Western handouts - it was not a reciprocal or mutually adaptive approach. This has made the reforms to be less successful.

\section{Reform And Development}

Reforms are essential requirement for successful implementation of development policies and programmes in less industrialized countries. The development process dictates flexibility, creativity, and innovation in administrative systems. Very often, the rigidly structured systems are ill-suited for carrying out massive developmental programmes. Reforming such systems become imperative if any genuine results are expected from any developmental efforts. Therefore, reforms are very functional to successful development around the world (Farazmand 2002:6).

Reform in developing countries may involve a number of structural and process changes and improvements. They may include sectoral structures and processes such as personnel systems by building the technical, professional, and administrative management capacity.... Another necessary change and reform is the genuine support of the political leadership for reform, for without the top support no reform can succeed. Reform in development means provision of key structural arrangements to facilitate administrative engagement in developing programmes. Reform means significant process changes by which implementation as well as policy development contributes to efficient and effective national development. Ibid.

Political and administrative elites and the business elites/invisible hands often pursue reform using the top - down, purposive models. Generally, both ordinary people and active members of the institutions or governance and administrative have little or no say in the reform process. Consequently, resistance may develop for a variety of reasons, inadequate resources, conflict interests, lack of adequate skills and training programmes, threat of the unknown, fear of possible loss of jobs or privileges, for instance, the resistance by oil and NITE workers, against privatization, as in the view of the antagonists the reform of the public sector reform programmes done so far had only benefited the power elite in terms of acquisition of the privatized public enterprises and the utilization of the proceeds therefrom. Such obstacles as well as political instability, such as the scenario that followed the Babangida reform; impair reform implementation, resulting in its failure.

\section{Trends In Reform}

Several reform movements emerged in the twentieth century. First came the post - war orientation of administrative capacity building that serve the political ends of anti-communist, anti-soviet, and anti-labour movements suspected of supporting world socialism. Administrative systems were built in less developed nations associated with the Western powers and world capitalism.

Second, the period of institution building in the 1960s provided a major impetus for bureaucratizing societies in less-developed nations under western influence. Bureaucratization, along with selective land and other agrarian reforms, prevented the peasant - based revolution by establishing state control over both rural and urban areas in developing nations. Bureaucratization was adopted as a means of implementing national policy and curtailing the power of local feudal lords and bid land owners, thereby given the centralized state room for maneuver.

Third, in the 1970s the state was further enhanced through administrative reform which facilitated the process of globalization. The major nationalization policies begun in the previous decade continued during these 
years. Further development of the welfare state was another major feature of this period, which resulted in the expansion of the public sector and its activities.

Forth, the 1980s marked the beginning of an era of reform with an opposite direction: privatization, commercialization, and marketization, government retrenchment (Guy Peters, 1991) and debureaucratization (Caiden, 1991) now replaced the earlier trends of nationalization and public sector development. Downsizing, public sector retrenchment, and other policies emanated from the global sources of capital power, led by the United States and Britain. This was the era of rapid globalization of capital and expansion of market at the expense of the public sector.

Since the 1980s, administrative reforms across the globe have led to privatization and cutbacks in governmental expenditures and activities. The fall of the Soviet Union has further accelerated the pace of globalization of capital. Most governments in the developing world have been pressured by the globalizing states and trans-world corporations to promote such globalization (Farazmand 2002:7).

Supra-governmental international organizations such as the World Bank, the International Monetary Fund, and the World Trade Organization have been instrumental in enforcing the dominant role of globalizing states and transnational corporations around the world. Structural adjustment and privatization have been the key strategies to promote globalization of capitalism and surplus accumulation of capital (Farazmand, 1998).

Consequently, the welfare state has been dismantled in favour of corporate globalization with massive displacement effects for labour and the peasantry all over the world. While globalizing corporations have amassed wealth and power, less developed nations has been forced into a "race to the bottom" (Korten, 1995, Farazmand, 1999).

Fifth, reform efforts in the 1990s have further enhanced the market based philosophy of private sector managerialism and administration of the corporate state function. Public administration has been reoriented going from a public to a security - corporate emphasis. As a result, an expanded military, security, and police role has come to characterize the new corporate administrative state and public administration in both industrialized and developing nations (Farazmand, 1997; and Davey, 1995).

This structural development has many manifestations in advanced industrialized, and also in developing nations. Expanded budget expenditures for more prisons, larger police forces and more equipment in the name of crime prevention, deregulation, corporate subsidies and military - orient investments are a few examples. A "new social contract" has emerged from the welfare state to the police state (Davey, 1995), and the welfare administrative state. The result is administration of the "public" in place of public administration (Farazmand, 1997). Corporate elites dominate both public and private sectors in the globalization era, and the role of the dominant state is to enhance opportunities for further accumulation of surplus capital. The fall out is that corruption has been mounting at the highest levels of government across the globe, therefore, sounding the alarm of accountability and ethnical problems (Farazmand 1997). The new surge of concern for accountability in public service and administration is a worldwide phenomenon attracting the attention of governments, scholars, and policy developers alike (Farazmand, 2002).

The final reform trend is the emerging orientation whereby reforms are modifying the excesses of managerialism and market - based reforms. The Latin American countries quickly discovered that private sector, market - based managerialism was a failure because of immense social consequences and that the balance must be maintained between corporate managerialism and concerns for the environment, social equity and fairness in income distribution. A growing number of governments in developing nations are voicing similar concern. The dialectical pressure from below is emerging against the dominant globalizing corporations that tend to pillage the global village (Brecher, and Costello, 1994).

\section{State And The Provision Of Public Services}

Before the 1930s, the initial development thrusts were rooted in a free and open market system in which private ownership and free markets were advocated to bring greater efficiency and more rapid growth. This notion was based on the protestant ethnical philosophy popularized by Adam Smith, who believed that in a capitalist economy, people acting to develop their own self-interest will promote economic efficiency and the interest of the society as a whole (Oshionebo 2001). This view of individualism however, failed owing to the great depression of the 1930s, thereby creating doubts as to the ability of the private sector to continue to play the dominant role in the economic activities of a nation. The need for government intervention in the economy of countries was, therefore, triggered as a result of the failure of the market economy. This theory which was popularized by Keynes, therefore laid the background for the expanded economic role of government and led to massive government participation in the economy of various nations. In Nigeria, after independence in 1960, it was rather imperative for the political leadership to set the pace for development. This was thus; justified in order to mobilize the productive forces of the economy and promote rapid socio economic changes so as to accelerate development efforts and therefore, conquer poverty, disease, ignorance and hunger. 
The first national development plan $(1962-1968)$, which was formulated to ensure rapid development and effective management of the nation's resources, gave cognizance to the private sector to attract the inflow of foreign funds for reinvestment in the manufacturing sector. However, the expectation of such an economic plan to stimulate the development of a vibrant private sector and marginalize public sector participation in production activities was not met. In fact, the little fund that ever came in was directed to the commercial rather than industrial sector of the economy (Oshionebo 2001).

In view of this shortfall in private sector investment, government felt that the sector was not capable of generating the leading impetus on the economic development arena. Moreover, government suddenly had windfall gains from crude oil sales in the early 1970s, and therefore believed it was in a better position than the private sector to generate necessary impetus for the desired economic development and socio-economic transformation of the country. Thus, the public sector took up the challenge to become the dominant sector in socio- economic development. Apart from the short fall in foreign capital inflow and the windfall in crude oil sales, there was a strong desire to triumph over poverty as well as distribute the benefits of industrialization generally in the society. This prompted the Nigeria government, like in many other developing countries, to occupy the central stage of commercial and industrial activity.

At the backdrop of this economic dominance, therefore, the philosophy of government in the preparation of the Second National Development Plan $(1970$ - 1974) indicated that it was thus most important single institution for ensuring the transformation of growth into development. In setting the pace for economic development, government, however, decided that the core civil service was inherently incapable of meeting the entrepreneurial requirement of managing development oriented institutions. It thus, established agencies, statutory corporations and companies as tools of public intervention in the development process (NCEMA 2003: 41).

Government then went into the business of establishing industries that were considered strategic and capable of stimulating socio-economic growth and development, while many manufacturing and commercial enterprises were operated in direct cooperation with private companies. Government also acquire majority shareholding in oil companies, insurance companies, banks and newspapers. As Oshionebo (2001) states the State's involvement in the industrial and commercial fabric of society was so comprehensive that it was impossible in the 1980s to imagine any undertaking in which government (Federal, State and Local) did not have interest, wholly or partially.

According to Orubu (2001) Nigeria had the largest number of public enterprise in African in 1986, with 600 enterprises at the federal, state and some 900 smaller ones at the state and local government levels.

Such was the enormity of government investment in economic activities that the problem of funding and managing those enterprises effectively and efficiently for a minimal return because difficult. There is no gainsaying that over the years, successive governments have decried the inefficiency and poor performance of most public enterprises. As Orubu (2001:3) notes, public enterprises accounted for significant proportion of the total foreign debts of many Africa counties, thus contributing to the debt of such counties during the 1980s.

\section{Public Service Reform In Nigeria}

There is a pervasive desire by countries especially those that are categorized as third world, which include Africa and Nigeria for the attainment of the status of a developed nation or continent. In Nigeria nationalist agitations for political independence from the colonial master, Britain, were anchored on the expressed desire for instituting a process of development that will raise Nigeria to the status of world power and also ensure the good life for the generality of her people (Deakaa, 2006:38). To do this, the Nigerian state needed to be expanded both in scope and in its role. Deakaa, continued that the expansion of the role of the state led to the expansion of an enormous and inefficient bureaucracy that became a great burden on the resources of the nation and government had to address this.

Although the Nigeria state's public sector reform in line with global trend per se is something that is very recent dating back to the 1980s, even the colonialist were concerned about the efficiency of the service. Chikwendu in Vingil (2006: 95) has identified five major public service reforms during the colonial era as including: The Tudor David Commission; the Harigan Commission; the Huge Food Commission; the Gorsuch Commission; and the Mbanefo Commission.

After independence, the first civilian's administration did not carry out a substantial public service reform. However, the military coup of 1966 in which General J. T. U. Aguisi Ironsi became the first Nigerian Military Head of State Ironsi promulgated a decree that unified the Civil Service Structure of the Federation.

In 1972, notes Vingil (2006:98) the military administration of General Yakubu Gowon instituted a Public review Commission under the Chairmanship of Chief Jerome O. Udoji. The commission was to work under the following terms of reference: To examine the organization and structure of the public service; To investigate and evaluate their methods of recruitment, condition of service and staff development programmes; To examine the existing pension and supernatural schemes in the public and public sectors; To make 
recommendations that would facilitate inter-sectoral mobility, without detriment to the retention of different and qualified personnel in public services; and to ...establish appropriate salary scales. As it turned out, the outcome of the Udoji Commission could only be appropriated in the salary increase and wards in 1974.

But we should not lost sight of the fact that the recommendations of the commission clearly titled towards what became the hallmark of public service reforms of the 1980s. notes Vingil (2006:99) the summary of the Udoji's recommendation were: That the concept of result oriented management be adopted; that a United structure be introduced; that the administration be transformed into management; that may be dependent upon job content and performance; that promotion be based on merit and not seniority; that public sector compensation be related to private sector compensation; that financial management be strengthened and modernized; and that personnel management practice be modernized.

Of course mention must be made of Murtala's effort to improve the service in which there was the removal by retrenchment or dismissal from office of some 10,000 public servants, approximating $1.5 \%$ of all those in public employment (Dudly, 1982:104).

Since reforms are implemented by the Civil servants, the thinking of succeeding administration in Nigeria was that an efficient service would serve as a pivotal for effective and efficient service delivery.

\section{Globalization And Public Sector Reform In Nigeria}

Mention must be made that public service reforms as it affect economic transformation, notes Abu, (2002:11) dates back to the late 1950s, when import substitution strategy was meant as a policy to encourage inward development and de-emphasize importation of foreign goods so that the local industries could be stimulated and the markets expanded for commodities. This strategy was envisioned as a tool for industrialization and a source of increased job opportunities for Nigerians. This did not translate into the dreams that were envisioned by the people as the setting up of industries locally with heavy input importation, capital drain and high operational costs rendered the exercise a near failure.

The set of experts from the IMF and IBRD... dictated to us that we needed to embark on import substitution industrialization. We did without asking much question and the result today has been a number of assembly plants that cannot survive on their own and have constituted a drain on our economies. Worse still; there was a common neglect of agriculture generally but particularly food production (Obasanjo 1988:29).

The failure of this reform, notes Onimode (2001) also centered on the contracted problem of foreign debt crisis, debts that were incurred for financing of the reform policies. Obasanjo (1988:28) notes that the IMF and the World Bank designed the programmes and policies. Indigenous initiatives like the Arusha Declaration of Tanzania, the People Charter of Uganda, Socialist Alternative of Guinea and the socialist Revolution of Ethiopia were seriously opposed and made unworkable. The externally initiated and directed public reform strategies were meant to ensure disciplined, organized and expected outflows in order to attract foreign funds for investment. This did not meet with tangible success:

We were told we needed development plans. We did not ask questions as to why we needed such plans if our teachers never made plans before realizing their development. Our reason for making plans was because the World Bank demanded them and "donor" countries needed to see them.

Ake, (1989:144) thus outlines some of the reform programmes which he said were not systematically implemented as including expansion and diversification of agricultural export commodities, import substitution, export promotion and integrated rural development. Ake (1981) further noted that the reforms did not work because of the inherent contradictions within the economy - the high capital output ratio, coupled with the rudimentary development of infrastructures, limited opportunities for linkages and economies of scale made the reform programmes extremely difficult to succeed.

\section{Public Sector Reforms In Nigeria In The 1980s}

The decade 1980s marked the watershed as Nigeria completely immersed into the ocean waters of public sector reform in consonant with global trend. The country was not independent in this action. The reforms stemmed from handouts from western powers through the Breton woods system of the international finance. The Lure been the economic crisis occasioned by the oil glut. It got to a point that the Shagari's government had to compellingly carryout the reforms as a bail out for the economic predicament that the country suddenly found herself in. the Shagari regime did not carry out the actual implementation but before the overthrow of that government the background had solidly already been laid.

On $31^{\text {st }}$ December, 1983, Shagari's government was overthrown by the Major General Muhammadu Buhari. The Buhari regime did not found the reforms suitable, especially the aspects of currency devaluation, massive removal of subsidy, privatization and liberalization of trade and payments. Bangura (1989:142) maintains that Buhari's government was averse to the externally induced public sector reforms because it felt that the purported benefits were less than the losses. Specifically, the government argued that the devaluation of the currency would worsen the balance of payment problem, lessen the country's foreign earnings and bring about 
an astronomical increase in naira terms the amount needed for debt servicing. Finally, the government maintained that the inflationary rate would be much and real income of workers would drop, pave the way wage increases demand by workers.

As a way out of the problem, the government turned to the Middle East where it approached Saudi Arabia for a loan of 1.6 billion dollars but the IMF working through the United States government prevailed upon the Saudi government not to grant the loan (Dauda, 2006:60).

However, by the end of the administration, counter-trade agreement has been signed with several countries, valued at more than 2.5 billion, with Brazil accounting for about 40 percent of the total deal. Discussions were ongoing with SCOA and government about similar counter-trade agreement. Several European Economic members, especially France, Germany, Italy and the Netherlands with considerable balance of trade deficits with Nigeria welcomed the counter-trade arrangement (Gambari, 1989:149). Expectedly, Britain, especially, was not receptive to the counter-trade regime, as it threatened the volume of Britain's trade with Nigeria. Nigeria's relations with Britain started to experience some strains, and the breaking point came with the entrance of the Alhaji Umoru Dikko Saga.

\section{The Ibrahim Babangida Era}

If the previous administrations were cautions and threading at the periphery of globalized public sector reforms, the Babangida administration was not hesitant to position itself right in the centre of the gravity. The Structural Adjustment Programme, SAP, was the anchor of the reforms and the administration braved all odds to introduce it, in spite of the overwhelming rejection of the SAP by Nigerians. Deakaa (2006:43) says that SAP which was introduced in 1986, as a complex strategy was meant to among other things stimulate local production, diversify the economic basic of Nigeria from a monoculture to other sectors and enhance industrialization. That it also meant the withdrawal of the State in economic activities, currency devaluation, privatization and commercialization of hitherto state-owned enterprises, withdrawal of the State in economic activities, currency devaluation, privatization and commercialization of hitherto state - owned enterprises, withdrawal of subsidies and the elimination of trade tariffs etc. According to World Bank (1982:398), the main objectives of SAP were two - fold, namely to support a programme of specific policy changes and institutional reforms and to act as a catalyst for the inflow of external capital. Hussain (1987:2) however noted that the motivation for SAP in Nigeria stemmed from the desire to find solutions to the external debt problems faced by the country and the implicit expectations that the cash flow relief would free foreign exchange for domestic uses.

According to Hussain (1994) the public sector reform that was galvanized in SAP achieved some measure of successes:

That by 1988, output shut from its limited 2 percent growth in 1986 to almost 9 percent and by 1989and 1991 overall GDP growth averaged 5.8 percent annually dominated by the oil sector. Manufacturing production also grew from an average of 5.1 percent over the adjustment period, 1986-1991 from negative growth rate of 3.9 percent in $1986 \ldots$. In the area of external balance and diversification of the Nigeria economy, total merchandize export fluctuated during the period of adjustment, rising from 6.8 billion dollars in 1986 to 13.9 billion dollars in 1990 and then falling to 12.1 billion dollars in 1991. These fluctuations were not due to SAP but to oil sector. The period also witnessed increased indebtedness of Nigeria as the debt stock, which was 18.9 billion dollars pre - SAP period rose 33.2 billion dollars in 1991. Inflation, which averaged 18 percent between 1980 and 1985, rose to 24 percent between 1986 and 1991. By the end of 1992 it was over 46 percent and remained in that range up through 1993.

The consequences of the reform on the generality of Nigerians were devastating. There was a fall in real wages, collapse of infrastructure including water supply, electricity, transportation and high cost in education, health care and other services. The period witnessed general resentment from Nigerians especially among the working class. This reform strategy did not therefore chart the desired path that was required for development to take place (Deakaa 2006: 45).

When General Sani Abacha took over power in 1993, he jettisoned SAP, but he did not dismantle its structures. The regime was in any case faced with the battle of surviving when Nigeria became a pariah state such that, it tried to re-orient reforms towards the East, but the administration obviously was pre-occupied with the task of self-succession which diverted its attention from carrying out appreciable reforms.

General Abdulsalami Abubakar administration which succeeded that of the Abacha, continued with the SAP brand of public sector reforms such that in spite of its short life span it privatized and commercialized public enterprises to the extent that one can only find less than a handful of public enterprises that are still in the hands of government.

This trend was to be consolidated with the advent of the Chief Olusegun Obasanjo administration, who although castigated SAP for its inhuman posture when he was not in government, yet he continued with the SAP era public sector reforms: 
Thus with the advent of the Obasanjo administration in 1999, government made it clear that sustainable growth and development is the hallmark for realizing the desired standard of living for the people (Obasanjo's Economic Direction, 1999- 2000).

The overall economic strategy lies in a private sector-led economy with government divesting its holdings in enterprise where the private sector could perform better. Government is to be a catalyst that provides the enabling environment for the private sector to thrive. This essentially is the central tendency of the privatization and commercialization exercise (Deakaa, 2006:45).

The reforms have continued even with the present administration of President Goodluck Jonathan. The latest of these series of public sector reform is the much publicized deregulation of the petroleum sector of the economy.

\section{The Way Forward}

It is pretty difficult to find any third world country that has not carried out public sector reforms in line with the current global capitalist trend of free market economy. Some of the reforms have produced positive results, example including countries in South East Asia and some Latin American countries and yet lately some countries in the Middle East who, according to A World Bank Policy Research Report (1993:34), have attained successes because they have gotten the fundamentals right. In African too, countries that have embraced true democracy, have recorded successes.

That is to say there are a number of factors that are central to the success of public sector reforms.

In Nigeria one of the fundamental problems, experience has shown, were the apparent lack of macroeconomic stability, and the lack of prudent fiscal monetary discipline on the part those charged with the responsibility of carrying out the reforms:

The whole process was not transparent. Example, the Privatization Act stated categorically, that the Catchment area (i.e. Benue indigenes in respect of BCC PLC) should have the opportunity of acquiring the federal government shareholding in the economy.

The Memorandum and Article of Association states that in the case of transfer of... the company "transfer should be made to a cement manufacturer". The transfer to DIL, therefore contravene the Memorandum and Article of Association (Nigerian Tribune, May 25, 2000).

...Small cabal into the Technical Committee of the NCP in collaboration with two former managing directors of BCC Plc recommended Dangote Industries Ltd. This amounts to foul play (New Nigeria, May 2, 2000:20).

That is to say that implementation is the bane of public sector reforms in Nigeria.

Also, as advocated by some Latin American Countries, it is not just enough to carry out reforms in one fell swoop because the IMF or any authority for that matter wants it done, bearing in mind that as entities in the global economic and ideological competition, the sincerity of the dominant world bodies in working towards the promotion of real development in Third World counties out to be accepted with critical mind.

The reforms should be situated within the context of national needs, since the much purported gains of privatization, commercialization and marketization or to be straight forward, the public sector reform has not automatically led to economic Eldora do. As a matter of fact, in spite of these reforms, the Nigerian economy would have been in shambles in the absence of the oil wealth.

Most importantly, embracing externally induced reforms just because of the inevitable of globalization is quite dangerous. While there is absence o alternative to globalization, synergizing it with domestic strategies can be very helpful.

Finally, a strong political will on the part of the country's leaders would be quite handy. A situation where leaders have shown the propensity of leaving the officials changed with reform programmes get away with impurity their wrong doings such as stashing away proceeds of reforms in foreign and local bank accounts should be reversed.

\section{Conclusion}

Public sector reforms in the face of globalization meant privatization, commercialization, marketization and confinement of the government on the role of providing the conducive environment for the free-flow of market forces in the economy. Through the structural adjustment programme, this process actually begun in Nigeria in 1986, by the Babangida regime. Succeeding administrations have continued with the process. The overall goal of public service reform is to stimulate rapid economic growth. In Nigeria, the success of the reform programme is mixed.

Today, we face challenges of a different order. Our societies are overwhelmed by the strident consequences of globalization and its twin phenomenon of trade liberalization. The option open to us have 
narrowed as our increasingly shrinking world impose on our countries the choice of integration with several conditions or marginalization and stagnation...

...with inadequate infrastructure and fragile economies, and global shortage of capital and finance, globalization and liberalization portend grave uncertainties, or even risk. Our vulnerability is best illustrated by the statistics of our share of world trade. The collapse of commodity prices, in a world market dominated and shaped by the preferences of the major trading countries, had made mockery of the efforts of our farmers to increase productivity (Olusegun Obasanjo, 2000:30).

\section{References}

[1]. Ake, C. (1981). A. Political Economy of Africa. Harlow. Essex. Longman Publishers.

[2]. Ake, C. (1989). The Political Economy of Crisis and Crisis and Underdevelopment in Africa. Selected Work of Claude Ake. Juliu s Ihonvbele (ed) Lagos. JAD Publishers Ltd.

[3]. Allen, R. (1999) "New Public Management: Pitfalls for Central and Eastern Europe", Public Management Forum, Vol. 1:4.

[4]. Bangura, A. (1991). See Dauda, S. 2006 Nigeria's Foreign Policy. Ibadan. Daily Graphics Nig. Ltd.

[5]. Batley, R. (1999). The Role of Government in Adjusting Economies: An Overview of Findings. Birmingham: International Development Department, University of Birmingham, UK

[6]. Brecher, J. \& Costello, T. (1994). Global Village or Global Pillage: Economic Restructuring from the Bottom up. Boston: South End Press.

[7]. Caiden, G. E. (1991). “Administrative Reform”. In Adi Farazmand, (ed). Handbook of Comparative and Development Public Administration. New York Marcel Dekker.

[8]. Chikwendu (2006). In Vingil, S. 2006. Theory and Practice of Public Administration Selected Themes. $2^{\text {nd }}$ Edition Makurdi, Oracle Business Ltd.

[9]. Chittoo H. B. \& Gaojie (2003). “Is New Public Management an Outdated Model”, Century China. Hong Kong (China).

[10]. Dauda, S. (2006). Nigeria's Foreign Policy. Ibadan Daily Graphics Nigeria Ltd.

[11]. Davey, J. (1995). "The New Social Contract": America's Journey from Welfare State to Public State. Westport C. T. Praeger.

[12]. Dudley, B. J. (1982). An introduction to Nigerian Government and Politics. London. Macmillan.

[13]. Dunleavy, P. \& Hood, C. (1994), "From Oil Public administration to New Public Management" in Public Money and Management, Vol. 14:3.

[14]. Farazmand, A. (ed) (2002). Administrative Reform in Developing Nations. London. Fraeger.

[15]. Friedman, T. (1996). "The Revolt of the Wannabes: Globalization Suffers a Backlash" in New York Time, 7 February http:/www.com.ng/.

[16]. Gambari, Sec. Dauda, S. (2006). Nigerian Foreign Policy. Ibadan. Daily Graphics Nig. Ltd.

[17]. Hussain, I. (1987). Structural Adjustment \& Development in Africa. Washington: World Bank.

[18]. Korten, D. (1995). When Corporations Rule the World. West Hartford. CT: Kamarian Press.

[19]. Manning, M. (1996). "Improving the Public Service" Unpublished paper. London. Vol. 67.

[20]. Minogue, M. (2001) "Shoould Flawed Models of Public Management be Exported? Issues and Practices", IDPM University of Manchester, UK

[21]. March, J. G. \& Olesen, J. P. (1984). "The New Institutionalism: Organizational Factors in Political Life". American Political Science Review.

[22]. New Nigerian, May 2, 2000.

[23]. Nunberg, B. (1995). "Managing the Civil Service: Reform Lessons from Advanced Industrialized Countries" Washington, World Bank, Discussion Paper 204 http://www.com.ng/.

[24]. Obasanjo, O. (2001). "The Imperative of Economic Development for Democracy", at the Inauguration of the Presidential Advisory Council on Investment Abuja. In Ad' Obe (2001). A New Dawn. (Vol. 2) A Collection of Speeches of President Olusegun Obasanjo. Ibadan Spectrum Books Ltd.

[25]. Obasanjo, O. (1988). "The World Bank and the Structural Adjustment in Nigeria" in Alkali, R. A. (1997). The World Bank and Nigeria: Cornucopia or Pandorais Box? Kaduna. Baraka Publishers Ltd.

[26]. Onimode, B. (1985). An Introduction to Marxist Political Economy London. Zed Books.

[27]. Orngu S. C. (2008). Political Patronage and the Challenges of Development in Contemporary Nigeria. Makurdi. Book makers.

[28]. Orubu, C. O. (2001). "Public Enterprises Reform: Concepts, Processes and Opinion" Paper Delivered at the NCEMA Training Programmes on Public Enterprise Reforms, 28 may - 8 June, 2001. Ibadan.

[29]. Oshionebo, B. O. (2001). "Public Enterprise Performance and Management in Nigeria. An overview" Paper Delivered at the NCEMA Training Programme on Public Enterprise Reforms, 28 May - 8 June, Ibadan.

[30]. Osborne, D. \& Gaebler, R. (1992). Reinventing Government. Reading MA: Addison - Wesley.

[31]. Peters, B. G. (1994). "Government Reorganization: A Theoretical Analysis" In Ali Farazmand, ed. Modern Organization: Administrative Theory in Contemporary Society West Port. CT: Praeger.

[32]. Public Enterprises Reform Training Programme Report, 2000/2001. National Centre for Economic Management and Administration. NCEMA. 2000. Ibadan. Nigeria.

[33]. Schick, A. (1966). The Spirit of Reform. Managing the New Zealand State Sector in a time of change. Wellington. Treasury http:///www.com.ng/. retrieved.

[34]. Span, R. N. (1981). "Fashions and Fantacies in Public Administration" Austrian Journal of Public Administration Vol. 40. http://www.com.ng/.

[35]. Sutch, H. (1999). "The Relevance of New Public Management for Transition Countries", Public Management Forum. http://www.com.ng/.

[36]. The East Asian Miracle. Economic Growth and Public Policy. World Bank Policy Research Report. Oxford University Press.

[37]. Tomlinson, J. (1996). "Cultural Globalization: Placing and Displacing the West", the European Journal of Development Research. Vol. 8:2, December. http://www.com.ng/.

[38]. Tribune, Editorial Comments, 24 May, 2000.

[39]. Wikipedia.org/wiki/internation_relations.

[40]. World Bank Report 1996/1997. 